\title{
Erratum to: Effect of the pollution level on the functional bacterial groups aiming at degrading bisphenol $A$ and nonylphenol in natural biofilms of an urban river
}

\author{
Wei Cai $^{1} \cdot \mathrm{Yi} \mathrm{Li}^{1} \cdot$ Peifang Wang $^{1} \cdot$ Lihua Niu $^{1} \cdot$ Wenlong Zhang ${ }^{1} \cdot$ Chao Wang $^{1}$
}

Published online: 13 January 2017

(C) Springer-Verlag Berlin Heidelberg 2017

Erratum to: Environ Sci Pollut Res (2016) 23:15727-15738

DOI 10.1007/s11356-016-6757-3

The original publication of the paper contains a mistake.

There should be 2 corresponding Authors (Yi Li and Lihua Niu).

The online version of the original article can be found at doi:10.1007 /s11356-016-6757-3.

Yi Li

envly@hhu.edu.cn

$\triangle$ Lihua Niu

Nlhnq55@163.com

Key Laboratory of Integrated Regulation and Resource Development on Shallow Lakes, Ministry of Education, College of Environment, Hohai University, Xikang Road \#1, Nanjing 210098, People's

Republic of China 